Paweł Bachmat

\title{
Agreeing on the type and severity of the penalty in criminal proceedings in Poland
}

\author{
Uzgodnienie rodzaju i wysokości kary w postępowaniu karnym w Polsce
}

\begin{abstract}
The Polish Code of Criminal Procedure provides for three paths in which it is possible to agree with the accused the type and severity of the penalty imposed on him by the court, provided that taking evidence by the court is waived. The first possibility occurs during the stage of preparatory proceedings, being an agreement with the prosecutor, so that a lengthy evidence process is not carried out. The second option applies after the indictment has been brought to court, while the third one may be used by the accused until the end of the first interrogation of all the accused. It requires submitting a relevant application.
\end{abstract}

Keywords: ECPRD, criminal proceedings

Polski Kodeks postępowania karnego przewiduje trzy możliwe ścieżki uzgodnienia z oskarżonym rodzaju i surowości kary nałożonej na niego przez sąd pod warunkiem, że zrezygnuje się z przeprowadzenia dowodów przed sądem. Pierwsza możliwość pojawia się na etapie postępowania przygotowawczego i ma formę porozumienia z prokuratorem, dzięki czemu nie przeprowadza się długiego procesu dowodowego. Druga możliwość występuje po wniesieniu aktu oskarżenia do sądu, trzecią natomiast oskarżony może wykorzystać do końca pierwszego przesłuchania wszystkich oskarżonych (składa wówczas odpowiedni wniosek).

Słowa kluczowe: Europejskie Centrum Badań Parlamentarnych i Dokumentacji, postępowanie karne

\section{Referring to query No. 1}

Is there a differentiated proceeding in your criminal proceedings whereby the defendant acknowledges the facts in the circumstantial part of the indictment and agrees not to collect evidence on them?

In principle, the Polish Criminal Procedure Code ${ }^{1}$ provides for three paths, in which it is possible to make arrangements with the accused as to the type and severity of punishment imposed on him by the court, provided that he decides to dispense with the need to conduct evidence in the court in his case. The application of

1 The Criminal Procedure Code of the 6 June 1997, Journal of Laws 2018, item 1987, consolidation act as amended. 
each of these solutions depends on the fulfillment of additional conditions required by the Code of Criminal Procedure, which will be presented later in the reply.

The first procedure (based on Article $\mathbf{3 3 5}$ of the Code of Criminal Procedure) This procedure applies at the stage of preparatory proceedings and assumes the accused and the prosecutor agree on a penalty. Then the prosecutor, instead of an indictment, applies to the court for a conviction and to issue a sentence at the sitting part (without hearing parties) and imposing penalties agreed with the accused or other agreed measures provided for the offense. Issuing a verdict at a meeting means that the court will not conduct lengthy evidence proceedings in this case, assuming the circumstances established at the stage of the preparatory proceedings and granted by the accused to be proved sufficiently.

This type of agreement between the accused and the prosecutor is concluded provided that the following conditions specified in the Code of Criminal Procedure are met:

- the accused plead guilty,

- in the light of his explanations, the circumstances of the offense and his guilt are beyond doubt,

- moreover, the attitude of the accused indicates that the aims of the proceedings will be achieved.

In such a case, the prosecutor may refrain from carrying out further evidence activities. Prosecution may also limit them, in a situation where there is a need to assess the credibility of complex explanations. Evidence is carried out only to the extent necessary for this. In any case, however, if necessary to protect the evidence of a crime against their loss, deformation or destruction, procedural activities should be carried out to the extent necessary. In particular it is allowed to conduct visual inspection, if necessary with the participation of an expert, search or activities listed in Art. $74 \$ 2$ point $1^{2}$, and to take other necessary actions against suspect, including blood, hair and body secretions examinations.

When using the procedure of Art. 335, instead of an indictment, the prosecutor requests the court to issue a conviction at meeting and decide on penalties or other measures provided for the accused of the offense, which the prosecutor agreed with the accused. It should be emphasized that the prosecutor, as part of agreement with the accused on the type and severity of the penalty, is obliged to take into account the interests of the injured party. The agreement may also include issuing a specific decision regarding the costs of the process.

Alternatively, the prosecutor may file an indictment and attach to it a request for a conviction at the meeting and a decision on penalties agreed with the ac-

2 The provision is about performing external body examinations and other tests not combined with violation of body integrity; in particular, the accused may take fingerprints, photograph him and present for reconnaissance purposes to other persons. 
cused or other measures provided for the alleged offense. The legally protected interests of the injured party also need to be taken into account. Moreover, the circumstances of the offense and guilt the accused are not in doubt, statements of evidence made by the accused are not inconsistent with the findings made, and the accused's attitude indicates that the objectives of the proceedings will be achieved.

One should emphasize that the prosecutor's request for a convictive judgment and a decision on penalties or other measures agreed upon with the accused is not binding on the court. In other words, the court has two options:

- to grant the application, then no evidence proceedings are taken and the court condemns the accused to an agreed penalty. However, the court is obliged to ask for the consent of the victim. Acceptance of the request is possible only if the victim does not object to it, duly informed about the date of the meeting. In addition, the court may make the granting of the application conditional on compensation by the defendant of the damage caused in whole or in part or on compensation for the harm suffered. He may also correct the proposition regarding the penalty and make the granting of the application conditional upon the prosecutor's making the change on severity of punishment, which should be also accepted by the accused.

- to refuse the application if it considers that there are no grounds for it. Then the court returns the case to the prosecutor. Or if the application was submitted next to the indictment, it proceeds to hear the case on general principles.

\section{The second procedure (based on Article 338a of the Code of Criminal Procedure)}

This procedure applies at the end of the preparatory proceedings and when the indictment has been filed with the court, at the initial stage of the judicial proceedings, known as "the initial prosecution review before the start of the dispute." In such a case, the accused may, prior to delivery of the notice of the date of the trial, submit an application for a conviction and imposing the proposed penalty or measure, forfeiture or compensation measure without taking evidence. The accused's application may also concern the issue of a specific decision regarding the costs of the trial. The possibility of filing such an application applies only to perpetrators who have been charged with an offense punishable by a maximum of 15 years after deprivation of liberty.

- the court may grant the accused's request if the circumstances of the offense and guilt are not in doubt and the defendant's attitude indicates that the objectives of the proceedings will be achieved. This request can only be accepted if the prosecutor and the injured party, duly informed of the date of the meeting, do not object to this.

- the court may refuse the application and proceed to examine the case on general principles. 


\section{The third procedure (based on Article 387 of the Code of Criminal Procedure)}

The accused may use this regulation until the end of the first interrogation of all the accused at the main trial. He may then apply for a conviction and imposing a specific penalty or measure, forfeiture or compensatory measure without taking evidence. The application may also concern the issue of a specific decision on the costs of the trial. If the accused has no defender of his choice, the court may, at his request, appoint him an ex officio defender.

This right applies only to those accused who have been charged with a crime punishable by up to 15 years imprisonment.

The application is not binding on the court. In response, the court may:

- grant the application for a conviction when the circumstances of the offense and the accused's guilt are not in doubt and the objectives of the proceedings will be achieved despite not conducting the trial in full. Acceptance of an application is possible only if the prosecutor does not oppose it, as well as the injured party duly notified about the date of the trial and instructed about the possibility of the accused submitting such an application. The court may condition taking into account of the accused's application subject to making the change it indicates, e.g., regarding the penalty severity.

- the court may refuse the application and return to hearing the case on general principles.

It is worth adding that, by granting the request, the court may consider the evidence listed in the indictment or documents submitted by the party to be disclosed. With the consent of the parties present, the court may conduct evidence proceedings only partially, if the explanations of the accused who plead guilty are not in doubt.

\section{Referring to query No. 2 (a)}

If yes, is this procedure applicable to all crimes or is there any exceptions for some of them? If there are exceptions - for which crimes?

The answer to this question depends on the particular procedure used by the accused.

In the case of following the procedure based on Art. 335 of the Code of Criminal Procedure, one should remember it can only be applied to perpetrators of less serious crimes, known as offenses ("występek"). Pursuant to the penal code ${ }^{3}$ (Article $7 \$ 3$ ), the offense is punishable by a fine above 30 daily rates or above

3 The Criminal Code of the 6 June 1997, Journal of Laws 2018, item 1600, consolidation act as amended. 
5000 PLN, restriction of liberty exceeding one month or imprisonment exceeding one month.

However, this procedure does not apply to more serious crimes known as crimes ("zbrodnie"). A crime is a prohibited act punishable by imprisonment for not less than 3 years or a more severe penalty (Article $7 \$ 2$ of the Penal Code). The more severe penalty is the penalty of 25 years imprisonment or life sentence.

Regarding the procedures of Art. 338a and 387 of the Code of Criminal Procedure will apply only to those accused of criminal acts (offenses and crimes) punishable by a penalty not exceeding 15 years imprisonment.

\section{Referring to query No. 2 (b)}

If yes, what are the consequences of applying the procedure to the defendant? Is the Court required to award a more favorable sentence, e.g., reducing the sentence of imprisonment by $1 / 3$, replacing life imprisonment, etc.?

In each of the cases presented above, the court decides freely whether it will agree to the submitted application or not. In other words, in none of these cases the court is obliged to impose a penalty in the type and degree of severity of punishment agreed by the prosecutor and the accused or indicated by the accused.

At the same time, the court has the right to make a counter-proposal and make granting the application conditional on a change being made, e.g., the adoption of a more severe penalty. In any case, it must be accepted by the prosecutor and the accused, and in practice also by the injured party. 